\title{
Play(ful) Pedagogical Practices for Creative Collaborative Literacy
}

Christine Portier, Nicola Friedrich \& Shelley Stagg Peterson

This is the pre-peer reviewed version of the following article: Portier, C., Friedrich, N., \& Peterson. S. S. (2019). Play(ful) pedagogical practices for creative collaborative literacy, The Reading Teacher, which has been published in final form at doi:org/10.1002/trtr.1795. This article may be used for non-commercial purposes in accordance with Wiley Terms and Conditions for Use of Self-Archived Versions.

\begin{abstract}
With the goal of supporting children's writing and content area learning using play as a pedagogical model, K-1 teachers' action research projects involved children collaborating to create texts for a range of purposes. Their project activities were analyzed for their starting points/motivators, student- and teacher-roles, and artefacts. The activities took the form of small initiatives, a range of themes connecting curriculum areas, and imaginative scenarios. Within each, teachers took on various roles to support student interactions and scaffold literacy learning, while students responded through collaboration, creative expression, and writing. Each activity addressed curriculum objectives related to literacy, while presenting children with opportunities to engage in collaborative, play(ful) learning with peers and/or the teacher and express their learning through creative means. These projects show that there does not have to be a disconnect between the achievement of curriculum objectives and the implementation of play(ful) learning activities.
\end{abstract}

This paper shares action research projects where teachers brought writing experiences into the creative, play, and collaborative activities of their Kindergarten and Grade 1-2 students.

\section{PAUSE AND PONDER}

- In what ways have you integrated play(ful) activities in your classroom? Were there any factors that made this endeavor challenging?

- Have you ever tried stepping out of the "instructor" role and joining in with the students' collaborations? What insights did you gain from this new perspective?

- How do you decide which texts your students will explore? Who creates the audience for their written messages?

- How might you involve students in shaping how texts are used in the classroom? 
Ms. Logan stood in line at the counter as the customer ahead of her signed her name to receive a pumpkin order. As she waited, she examined the price list and decided she would add another pumpkin to her order. She approached the counter and said, "I would like to buy a large pumpkin, please." The two girls working the booth glanced at the assortment of pumpkins and then looked back at Ms. Logan. One of the girls said, "Sorry, we only have small pumpkins left." Ms. Logan asked if she could place an order. The girls handed her a clipboard, paper and pencil, and instructed her to write her name and phone number beside her order. Ms. Logan provided the information, thanked the girls, and then moved aside for the next customer in line.

At first, the reader might think that this interaction took place at a farmers' market.

Instead, we captured it within a Kindergarten classroom in Northern Ontario, Canada. Each year, Ms. Logan, an early childhood educator, and her co-teacher, Ms. Ritter, enjoyed taking their 3-5year-old students on excursions to the farmers' market. Unfortunately, this Autumn saw the closure of their local market, so they decided to recreate the experience in the classroom.

The students transformed objects (e.g., stuffed orange tissue paper; a puppet theatre frame; an empty bookcase) by assigning new meanings within the dramatic play context of a farmers' market. This process of assigning new meanings involves the symbolic thinking similar to that needed to learn to read and write (Pellegrini, Galda, Dresden, \& Cox, 1991). Moreover, children's use of social language (e.g., explicit references, elaborated nominal groups) and narrative language during dramatic play develops their literate language (Vedeler, 1997; Author, 2015b).

In the Canadian province of Ontario, in which we live and work, the Kindergarten program is based on a principle that "play is a means to early learning that capitalizes on children's natural curiosity and exuberance" (Ontario Ministry of Education, 2010, p.13). Teaching practices are informed by research showing that play facilitates the development of complex abilities, such as literacy (Bodrova \& Leong, 2015; Pellegrini,1980). Research findings across many decades (e.g., Bennett, Wood \& Rogers, 1997; Bodrova \& Leong, 2007; Moyles, 2015; Vygotsky, 1978), show how play can provide an authentic context or activity to foster young children's language, literacy and all other learning.

In this paper, we describe how Kindergarten and Grade 1 teachers used play(ful) activities to support children's literacy and content learning and we show how other teachers might modify or expand literacy instruction to include play(ful) activities.

\section{Play-Literacy Connection}

As early childhood researchers working with teachers of young children, we analyzed the action research projects that they put into practice to support their students' oral and written language development. Our work is informed by literacy research from an emergent literacy perspective, which recognizes children as meaning-makers who actively develop and refine their 
hypotheses about the form and function of print as they engage in authentic writing experiences (Harste, Burke, \& Woodward, 1984; Teale \& Sulzby 1986).

Much research and practice in early literacy over the past 30 years has been situated within this paradigm (Teale, Whittingham, \& Hoffman, 2018). In separate reviews of research examining play-literacy connections, both Roskos and Christie (2001), and Saracho and Spodek (2006), concluded that play environments foster the development of children's literacy practices.

Recent research suggests that play encourages language use (Author, 2015a, 2016a; Worthington \& van Oers, 2017), nurtures vocabulary development (Author, 2016b), and promotes early writing behaviours (Ihmeideh, 2015). Furthermore, the inclusion of literacyrelated resources (e.g., books, pencils, paper) and teacher guidance in play environments supports children's literate performances (Gerde, Bingham, \& Wasik, 2012; Quin, Gerde, \& Bingham 2016).

\section{Play as Pedagogical Practice}

Although the importance of play to child development is recognized by researchers (e.g., Bennett, Wood \& Rogers, 1997; Bodrova \& Leong, 2007; Moyles, 2015; Vygotsky, 1978), it is becoming increasingly common for policy makers and administrators to mandate that teachers of young children use didactic methods to support children's achievement of academic goals. Given the complex and uncertain relationships between teachers and the various institutions and stakeholders impacting policy and pedagogical decisions, early years teachers feel the strain between integrating play into pedagogy and emphasizing academics to meet curriculum expectations (Russell, 2011). Across the United States (Roskos \& Christie, 2009) and in the National Curriculum in the United Kingdom (Anning, 2015; Department for Education and Skills, 2013), the current emphasis is on standards-based education and teaching the basics to meet easily measured cognitive processes. There is often little room for play in early childhood classrooms.

The disconnect between early childhood research and policy indicates a need for research examining ways in which teachers can emphasize academics while maximizing play. In the following sections, we describe how K-1 teachers in northern rural and Indigenous Canadian classrooms brought literacy and other curriculum objectives together with play in their action research projects. We consider how early years teachers might modify or expand literacy instruction and student learning through play(ful) activity. Our research looks closely at teachers' and students' activity within teacher-initiated play-based activities designed to support the students' oral and written language development and offers examples from which other classroom teachers may draw ideas.

\section{Supporting Young Children's Emerging Literacy}


The Northern Oral Language and Writing Through Play (NOW Play) partnership is a multi-province research project that promotes collaboration between researchers, teachers, and early childhood educators through action research. Our aim is to support and improve the literacy learning of young Indigenous and non-Indigenous children in northern rural communities in Canada. This paper reports on one study within this partnership project.

\section{The Classroom Context}

In one eastern and two central provinces of Canada, we worked with educators in 10 northern, rural communities: two were First Nations communities with populations ranging from 200-500 people; and, eight were resource-based towns with populations between 400-7000 people. Sixteen educators participated. In the First Nations communities, three Indigenous educators taught children who spoke both an Aboriginal English dialect and Anishinaabemowin. The other teachers were non-Indigenous and worked with children who spoke English, with a few speaking German or Cree at home.

Most of the Kindergarten teachers organized their programs around learning and play centers, with instruction occurring throughout the day with varying groups (e.g., whole class, small groups, or individual students). Two of the Kindergarten teachers organized inquiry-based programs and integrated mini-lessons into activities. The Grade 1 teachers divided their programs into instruction and activity times and made efforts to integrate subject-learning.

\section{Documenting Action Research Activities}

Over the course of the partnership project, we made regular classroom visits to each of our participating sites to observe activities and meet with participants. During meetings with teachers, we discussed their ideas for play(ful) activities. Upon returning to the classroom, they recorded their own and the children's participation in the activities using iPods on tripods. They also took pictures of specific moments and the artefacts produced during activities. Data were uploaded to a secure Dropbox where we could review the materials prior to our next visits. Then, during an action research meeting, the teacher(s) reflected on their experiences and together we generated insights regarding the children's learning.

We organized the data (i.e., videos and transcripts, photographs, artifacts, fieldnotes from classroom visits, teacher reflections, and descriptions of the activities) into folders for each of 41 action research activities. The breakdown of activities by Grade level is as follows: 1 preKindergarten, 23 Kindergarten, 2 classrooms with Kindergarten and other grades up to grade 3, 11 Grade 1 classrooms, and 4 Grade $1 / 2$ classrooms. We created an excel table to enter information about the starting points/motivators, organization, created artefacts, and roles of students and the teacher(s) for each activity. Our analysis was informed by understandings from 
sociocultural theory (Vygotsky, 1978) about the role of social interaction, including adult mentorship and peer support, in children's literacy and all learning, and about children's construction of meaning motivated by their interests. We examined the 41 activities for patterns in how learning processes and products were met when teachers combined curriculum learning outcomes with the child-directed nature of play (Weisberg, Hirsh-Pasek, Golinkoff, Kittredge, \& Klahr, 2016).

In the next section, we share patterns seen across all the activities and include classroom examples.

\section{Explorations into Creative Collaborations for a Play(ful) Curriculum}

\section{What Were the Starting Points/Motivators?}

The teachers used the curriculum, school or community events, and the expressed interests of the students as starting points or motivators for the activities.

Curriculum. Twenty-two of the activities were motivated by the teachers' interest in meeting specific curriculum objectives, and then given shape in response to the teachers' and children's input and interactions.

For example, Janice (all names are pseudonyms) decided to shape an activity around the Grade 1 science topics of "Seasonal Changes" and "The Needs of Plants and Animals". From this starting point, she considered how to meet curriculum objectives in ways that would involve students in collaborative processes for creative outcomes. Her All About Spring activity integrated outdoor/environmental education (e.g., field walks), visual arts (e.g., dioramas, murals), drama (e.g., charades, pantomime), oral language (collaborative groups, partner research, presentations) and writing (e.g., research notes, graphic organizers, story writing).

Lila also began an activity from a curriculum starting point. She wanted to increase her students' writing by focusing on "creating original texts" and "constructing meaning from texts." With these in mind, she modified her Veterinarian Clinic play center. She set up the center as she had in previous years (e.g., medical props, stuffed animal pets, bandages), but for this new project, considered how different characters might use writing in the clinic.

Lila placed paper and writing materials in the center for the veterinarian to write prescriptions, and the receptionist to write down pet names and health concerns. She also modeled ways of using writing by entering the play context in-role as the "manager" to check inventory and take notes about items that were needed.

Community practice. For 11 activities, the teachers were motivated by an event or practice in their communities. For example, Sadie, is a Kindergarten teacher in a First Nations community, working with a community Elder who teaches Indigenous cultural classes. Sadie was motivated to bring some of the cultural practices into the classroom. She put her Campfire in 
the Woods plan into action after one such class, in which the Elder brought the children to a tipi where they shared food and listened to stories around a large fire.

Back in the classroom, Sadie placed some art materials into a box and gathered the students to an open space in the classroom. She didn't give instructions, but simply stated that they were all going to build a campfire. Working together, the students drew from their cultural class and added their own ideas to make a campfire and recreate activities around the fire.

Adrianna developed her Little Trees activity around an annual community event that raises money for the local women's shelter. Each year Adrianna asks her students to help her decorate a Christmas tree, which she donates to the shelter. This year, she used the event as a starting point for developing a more creative and cooperative activity. She began early in December with visualization exercises and journal reflections about carols. From these, themes emerged that helped the students plan interesting ways to decorate trees. Adrianna guided the students as they shaped their reflections into collaborative designs and material lists, and finally little decorated trees to donate (see Figure 1).

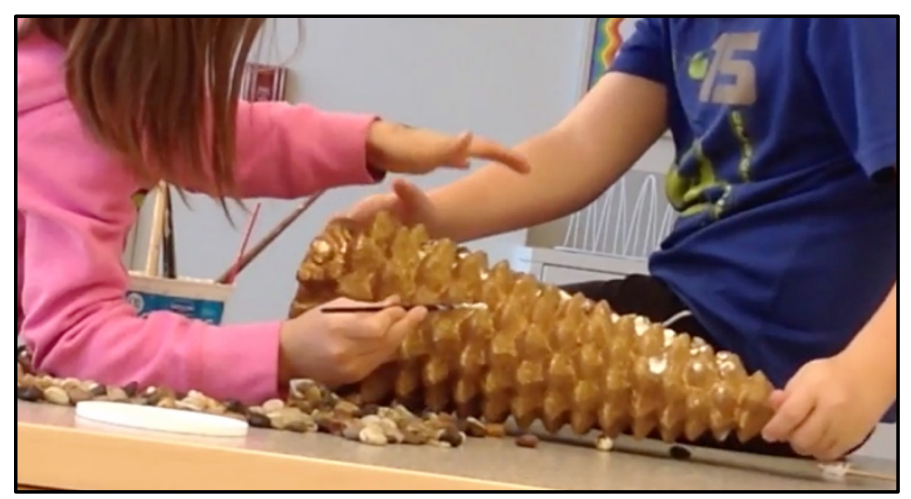

Figure 1. Grade 1 students collaborate to design and decorate a tree for a community fund-raiser.

Student interest. Finally, teachers develop eight activities around their students' interests. For example, the idea for Adrianna's Lemonade Stand activity came unexpectedly from her students as she was reading a pen pal letter to them. The letter contained some exciting details about a lemonade stand they had made. This idea completely captured the attention of Adrianna's Grade 1 students and they proposed their own lemonade stand project.

With Adrianna keeping the curriculum expectations in mind, the students planned and codeveloped collaborative and creative activities that extended into writing (e.g., plans, recipes, persuasive letters, scripts), art (e.g., posters, tickets, signs), science (e.g., construction), and math (e.g., tallies, graphs, number sense).

Beth, a Grade 1 teacher in a First Nations community, had been talking with her students about community signs and their meanings. Her students suggested that they might make some 
signs, and within moments, a larger idea about forming a sign company emerged. The students were so enthusiastic that soon the class Sign Company activity was underway. Beth provided materials and supported the students as they considered the different roles in a company (e.g., owner, manager, staff) and produced signs for items throughout their classroom and across the school.

\section{What Formats Did Teachers Select?}

We found that the teachers' activities could be categorized by how they were related to the classroom programs. We categorized them as initiatives, themes or scenarios.

Initiatives. Seventeen of the activities took form as single initiatives, ranging from one activity on one day to a few activities over a few days. For example, Polly's Kindergarten initiative, Signs in the Sand Table, focused on bringing writing into the children's sand table play. To do this, she prepared sign writing materials (e.g., popsicle sticks, card stock, markers, tape). After observing a group of children playing at the sand table, she joined their play to model, in-role, how signs might be created and used in the narrative. After a few minutes, she left the play center but left the sign materials behind.

Over the week, Polly repeated this process several times with different groups of children. In no time, the class was caught up in sign writing and finding ways to integrate them into their sand table play. Polly's initiative took only a few minutes each day for about a week, yet the effects were seen throughout the year.

Marcel's Terry Fox Day initiative was developed after the school's Terry Fox Day events (a fun run for charity). He organized the students into small groups where they collaboratively recounted the events and wrote/drew about it. Each student had their own paper to record ideas, which they later brought together to prepare small dramatizations for the class.

Themes. Twenty-one activities took the form of a theme that related several learning centers, connected curriculum areas, and extended over many weeks. For example, Polly's Castle theme involved the Kindergarten students in collaboratively constructing a large castle out of milk cartons, and later playing inside it with costumes and props. Polly read fiction and nonfiction texts to them about castles, and the students drew from these to create narratives for their collaborative play, write signs to post on the castle walls, and to design their own castles on the computer.

Marcel developed an Onster theme (Monster minus the $M$ ) that extended over several months, with periods of intense activity and then rest. In small groups, the students collaboratively created onsters and worked together to develop, illustrate and label them. Later the students brought together their small-group onster drawings to create a large class mural, where the onsters were named, placed in settings, and given actions. Later still, the students designed schools for the onsters, where they would learn the things that onsters needed to know. 
This theme focused primarily on oral language through collaboration and drama, and writing, moving from drawing, to single words or phrases, then sentences, and finally stories.

Scenarios. Three of the Kindergarten teachers developed activities that began as a small idea but, with the students' enthusiasm and input, grew to be large imaginative scenarios. Each scenario was framed by a dynamic fictional narrative that shaped the students' interactions, roles they enacted, and activities they developed.

Kahli's Leprechaun Mischief scenario developed from a short conversation about St. Patrick's Day. However, the students wanted to talk more about how they might prepare for leprechauns because they had heard about other students making traps. That afternoon, Kahli sent a note to parents suggesting that if they wanted to make traps, then the students could set them up in the classroom. The students and parents responded enthusiastically, and the leprechaun traps were set.

The students' enthusiasm inspired Kahli to stay late on Friday to take on the role of a group of leprechauns creating "mischief" in the room and leaving notes for the children. When the students arrived on Monday, Kahli joined in with the students as they entered their room to discover the mischief left by the weekend visitors. The students explored the room, talking and wondering, and decided to spend most of the day writing about the events and composing letters to the leprechauns.

Near the end of the day, Kahli invited Grade 1 students to their room, so the Kindergarteners could share their drawings and writings. Kahli's Leprechaun Mischief scenario developed over a week and ended with one full day when the students were immersed in the imaginative scenario.

In their classroom, Joan and Leslie did not know what to expect when they placed a tiny fairy door on the wall. As soon as the Kindergarten students noticed it, numerous activities developed in response. They wrote letters to the owner of the door, to which the teachers replied in-role as a fairy. They all made items for the Fairy, composed stories, discovered fairy books in the library, planted fairy gardens, created fairy-creatures to bring home, and captured their weekend activities with the fairies in photos, drawings and oral and written stories. This Fairy Door scenario engaged the Kindergarten students for over a month.

\section{What Were the Teachers' Roles?}

We found that the majority of participating teachers initiated the initiatives, themes, and scenarios and then took on various active roles to facilitate student learning.

Preparing materials. The teachers gathered the required resources to set up and stock the activity spaces. For example, Kahli gathered a variety of props and costumes that students could use to enact a number of roles (e.g., firefighter, nurse) in her Community Helpers initiative. For Ice Fishing, Tamara transformed a box into a 'frozen lake' and stocked the center with 
fishing related props (e.g., fishing rods, paper fish, templates for licenses) (see Figure 2). Marcel located sound files of ocean waves for a visualization exercise, which he used to develop a background story about pirates, islands, and buried treasure, which set up the extensive Irate themes (Pirate minus the $P$ ).

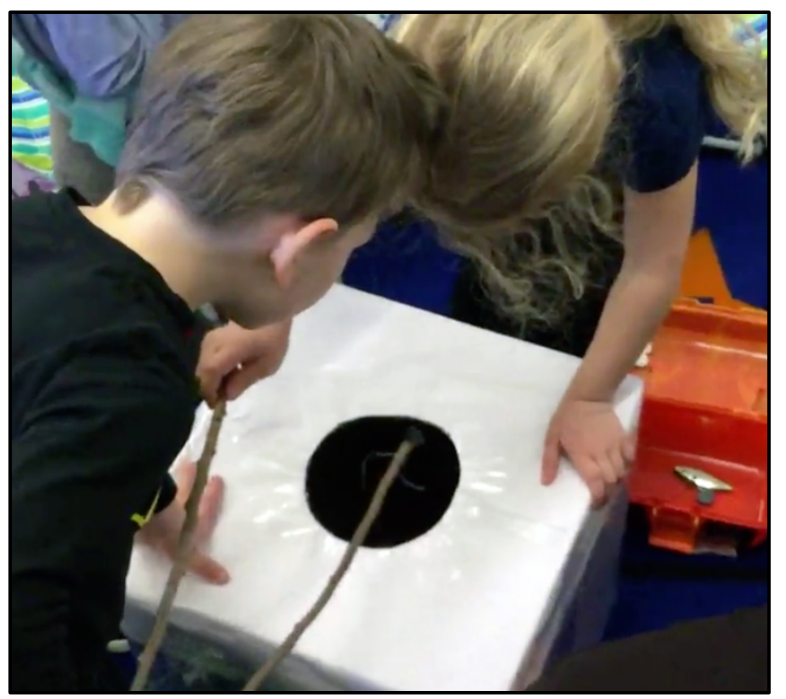

Figure 2. Kindergarten students peer down the fishing hole to look at their "catch".

Introducing ideas. We found that many of the teachers initiated their students' interest in the initiative, theme, or scenario by engaging them in a class discussion about the topic. For example, in response to Marcel's story about a childhood onster, the Grade 1 students shared their thoughts about how the creature looked, behaved, and sounded. In a similar discussion, the Kindergarten students in Kahli's class shared what they knew about leprechauns.

Other teachers introduced their initiative, theme, or scenario through a read-aloud or by sharing a stimulating story. For example, after reading a picture book, Tamara began her Adventure on the High Seas theme by challenging her Kindergarten students to follow clues beginning with a leaf that had "blown" down the hallway. Similarly, Marcel shared stories from his home province as a way to introduce the Grade 1 collaborative writing initiative, Irates. In contrast, Joan and Leslie introduced their Fairy Door scenario by positioning themselves directly in the scenario, wondering aloud about the origins of the tiny door, as their students arrived at school.

Responding to needs. Once the initiative, theme, or scenario was underway, we identified a shift in the teachers' roles. Rather than directing the activities, we found teachers were responding to the needs, ideas, and actions of their students. In most Kindergarten classrooms, this response was in the form of modelling. Some Kindergarten teachers responded 
to an observed need in their students' activity by modelling roles specific to their chosen theme. For example, Dawn modelled the role of cashier in Vegetable Stand, while Ruth, as part of her Taking Cookie Orders theme, modelled for her Kindergarten to Grade 3 students how they might take orders during their community fair.

Some teachers preferred to participate in a narrative or activity by taking on a role to "model while doing". For example, to show students what workers in a post office do, Lila entered the Mailroom center in role and actively sorted the mail into the appropriate mail slots. Similarly, Leslie took on the role of a customer when she entered the McDonald's center and placed her food order.

In contrast, we found that the teachers of older students created mini-lessons in response to their students' needs. For example, Adrianna organized mini-lessons to delve deeper into the ideas about animals that she heard her Grade 1 students share as they made puppets during the Forest Animals theme.

Participating in activities. Oftentimes, teachers responded to their students' needs, ideas, and actions by participating alongside them. For example, Adrianna worked alongside her Grade 1 students to design and build structures as part of the Lego ${ }^{\circledR}$ challenge for the Building Bridges initiative and to develop flavor ideas for lemonade to sell at the end of the Lemonade Stand theme. In contrast, Joan and Leslie, and Kahli worked with their students to maintain the Fairy Door and Leprechaun Mischief scenarios. In these two Kindergarten classrooms, the teachers worked with the students to come up with responses to the mysterious visitors in their classrooms.

Fostering writing. Oftentimes, teachers identified a need for written texts within the initiative or theme and responded accordingly, again, through modelling. For example, Polly's Signs at the Sand Table initiative took place at the sand table center in her Kindergarten classroom. After watching the students drive toy vehicles through the sand roads they created, she joined them to model how to create signs that might regulate the flow of traffic (see Figure 3). Similarly, when Kindergarten teachers Cassie and Dawn observed their students struggling to identify what they needed at the Grocery Store and Vegetable Stand centers, they modelled how to write a shopping list. 


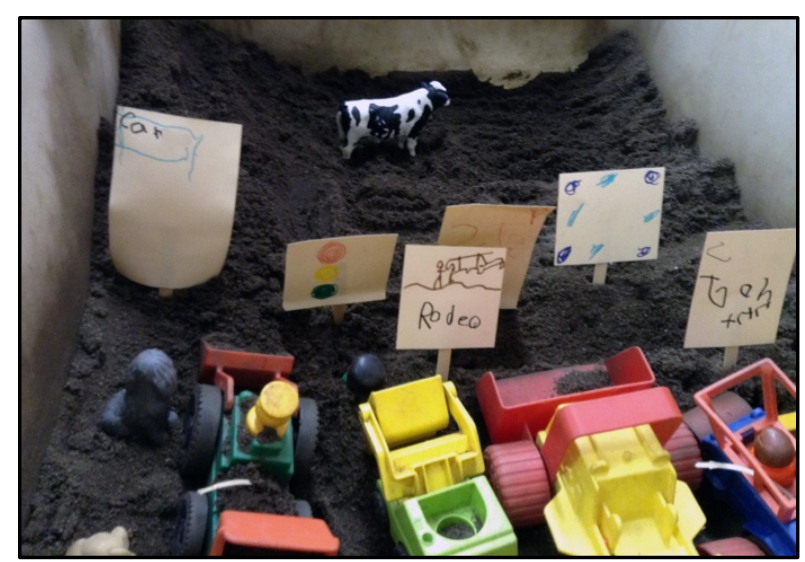

Figure 3. Kindergarten students bring sign writing into their sand table narratives.

Other teachers chose to model writing in role. For example, in her Mailroom initiative, to teach students how to address an envelope, Lila created a situation in which she had to send a parcel to her grandmother. She then thought aloud as she wrote her grandmother's name and address on the parcel. Similarly, to introduce print into the Farmer's Market theme, Leslie asked to order a pumpkin.

We found that all the teachers responded to their students' writing needs by scaffolding their writing attempts. The most frequent forms of scaffolding included encouraging students to sound out individual words and providing them with the appropriate vocabulary. Teachers of older students further scaffolded their students writing by asking guiding questions. For example, Marcel sat with each collaborative writing group and asked guiding questions to deepen their descriptive thinking in preparation for writing their Irate theme biographies in his Grade 1 classroom (see Figure 4).

Finally, some teachers chose to end their themes and initiatives with a writing activity. For example, to complete the Going Camping initiative, Lila grouped the Kindergarten students to reflect on what camping meant to them (see Figure 5). Following their discussion, the students drew pictures and wrote anecdotes about their camping experiences.

Other teachers asked students for specific types of responses. For example, at the end of the Kindergarten Planes \& Passports theme, Dawn placed sheets with the outline of a suitcase in the writing center. The students drew images and wrote letters and words to express the items that they would pack for an imagined trip. In most cases, the teachers also directed the students to share their writing and other created items with peers. 


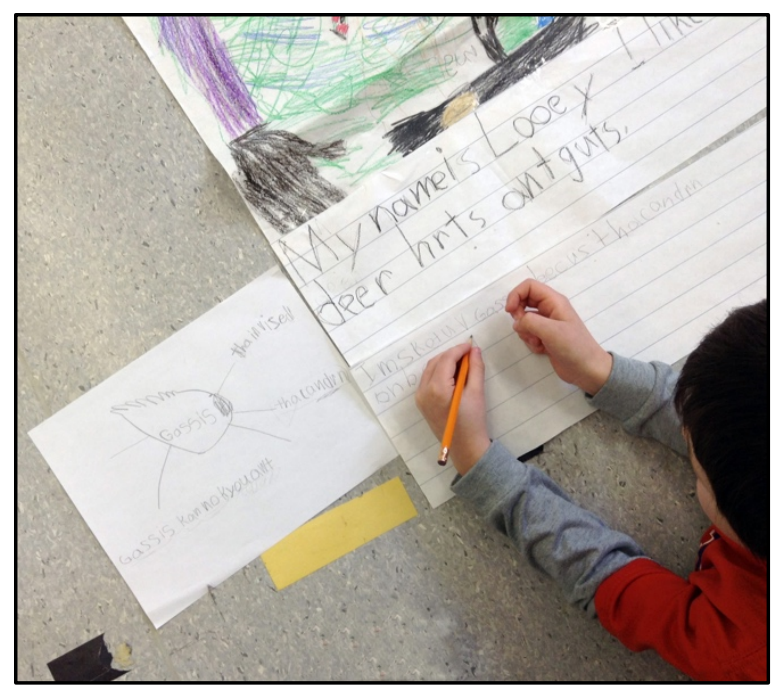

Figure 4. The teacher's guiding questions helped this Grade 1 student develop descriptive paragraphs about his irate character.

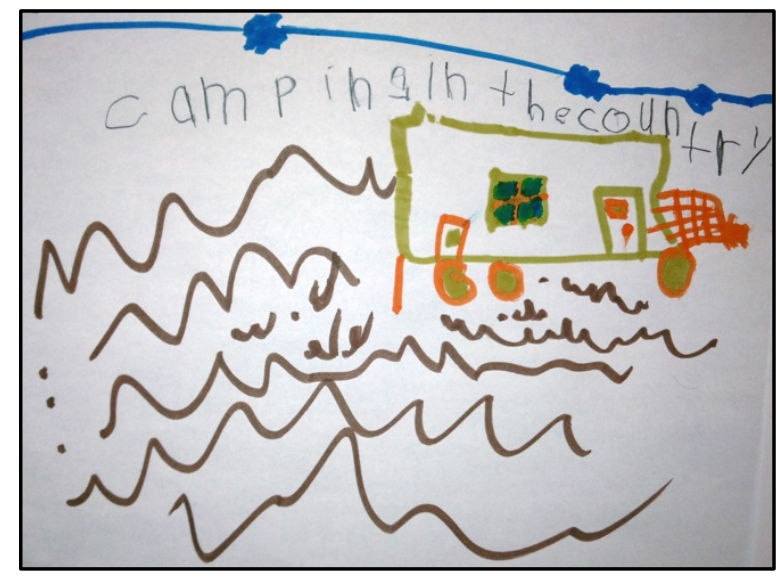

Figure 5. After playing in the camping center, a Kindergarten student reflects on his experiences camping and writes "camping in the country".

\section{What Were the Students' Roles?}

We found that the students directly responded to the different aspects of the teachers' initiatives, themes, or scenarios.

Responding to instructions. In most activities, the students were readily responding to the teachers' instructions. When directed, the students collaboratively developed, shared, and coordinated ideas and explored the available materials. For example, during the Building Bridges initiative, the Grade 1 students in Adrianna's class worked together in the "Building Zone" to create structures for appraisal in the "Testing Zone". Similarly, the students in Polly's Kindergarten class worked with her in small groups to create the walls for their milk carton castle.

Responding to ideas. The bulk of the students' activity was in response to the teachers' initial activity ideas. We found the students across the grades created or chose the content of their responses and how to present the products of their learning. Specifically, they developed narratives around different roles they enacted and created genre-specific texts to further a storyline or solve a problem.

During the Puppy Visit initiative, the Kindergarten students in Kahli's class responded to the puppy "visitor" by writing stories and letters to the puppy (see Figure 6), while the students in Polly's Kindergarten class took on roles, wrote texts, and developed their own narratives in the Taking Orders at the Restaurant initiative. Following Marcel's parameters, Grade 1 students created, presented and dramatized unique creatures as part of the Creating an Onster theme. 


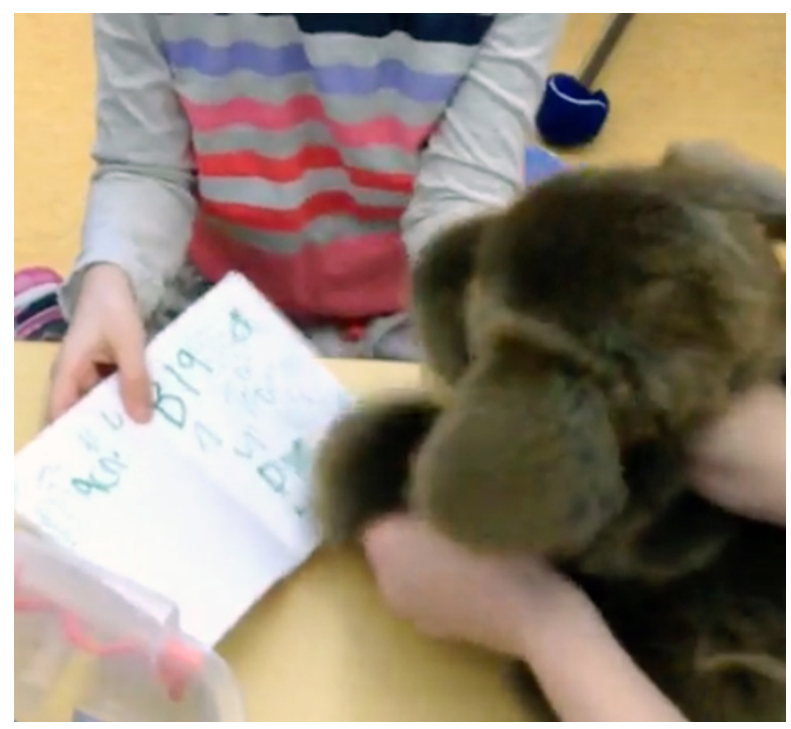

Figure 6. A Kindergarten student reads her story to the puppy "visitor".

Extending ideas. During student-initiated activity, the students often identified additional resources that would further their initiative, theme, or scenario. For example, the students in Jennifer and Leslie's Kindergarten class asked to make pies to sell in the booth of the Farmers' Market theme. In response, Jennifer and Leslie added pie templates, printed recipe cards and provided writing materials (see Figure 7). Grade 1 students in Adrianna's class created collaborative lists of the needed materials to support the Little Trees initiative.

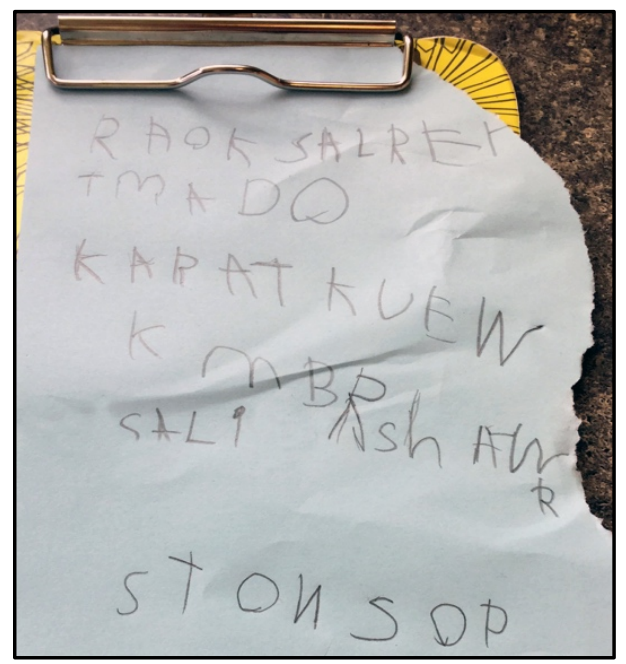

Figure 7. A Kindergarten student extends the recipe idea by writing a soup recipe. 
Directing their learning. We found some examples of students initiating their own learning activities, and these typically took the form of student-initiated dramatizations or writing activities, often in combination. In some classes, the students were involved with the overall planning of the initiative, theme, or scenario, with the students brainstorming ideas and providing suggestions in collaboration with the teacher. For example, Jennifer and Leslie worked with the Kindergarten students to brainstorm ideas for the activities and materials that would give shape to their selected Movie Theatre theme. Once they decided how they wanted to set up the center, both teachers and students considered roles for enactment and the materials needed to support these roles.

Similarly, when students in Adrianna's Grade 1 class decided to build their own stand for the Lemonade Stand theme, they experiment with different lemonade recipes, and then sold the lemonade school-wide (see Figures 8 \& 9).

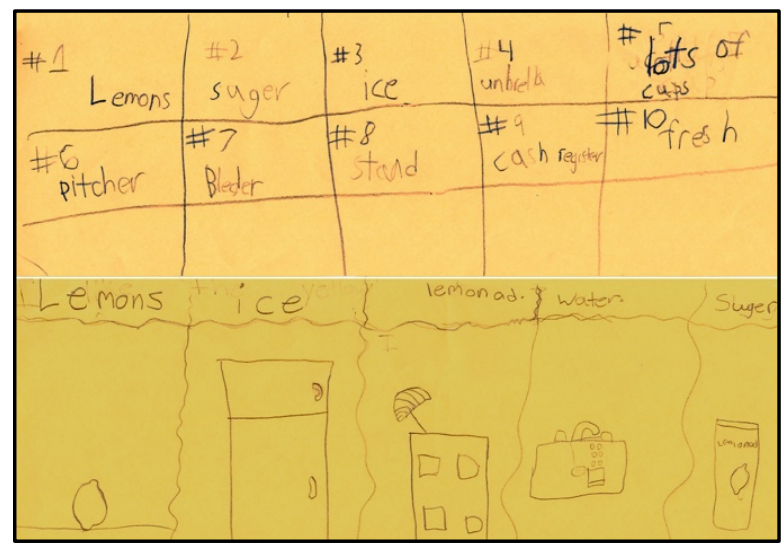

Figure 8. Grade 1 students wrote recipes for lemonade.

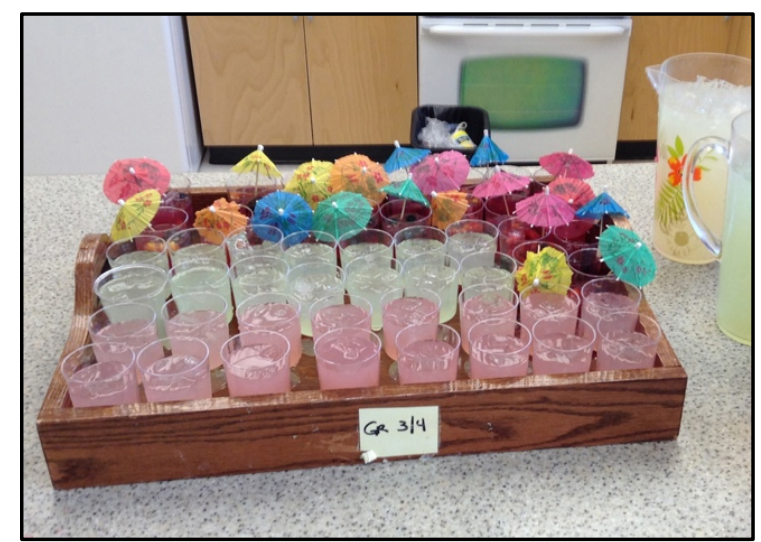

Figure 9. Following their recipes, Grade 1 students prepared refreshing drinks.

In other classrooms, students were responsible for specific activities within the larger initiative, theme, or scenario. For example, at the conclusion of the theme, All About Spring, students in Janice's Grade 1 classroom, came up with the final culminating activity of a class drama in the form of a talk show, with questions and responses based on their science learning.

\section{Literacy through Play(ful) Activity}

All the action research activities allowed participating students to engage with texts and fulfill curriculum objectives through play or in playful ways. We found evidence of literacy and other curriculum learning in every play(ful) activity. Students created texts and artefacts, which included bridges, murals, decorated trees, posters, dramatic performances, and dioramas, to name a few. In 15 of the activities, the students produced artefacts independently (e.g., "irate" maps 
and portraits, shopping lists), in 12 activities texts/artefacts were developed through collaborative endeavours with peer groups (e.g., "onster" schools, designing games), and in 14 of the activities the students were involved in both independent and collaboratively-created texts/artefacts (see Figure 10).

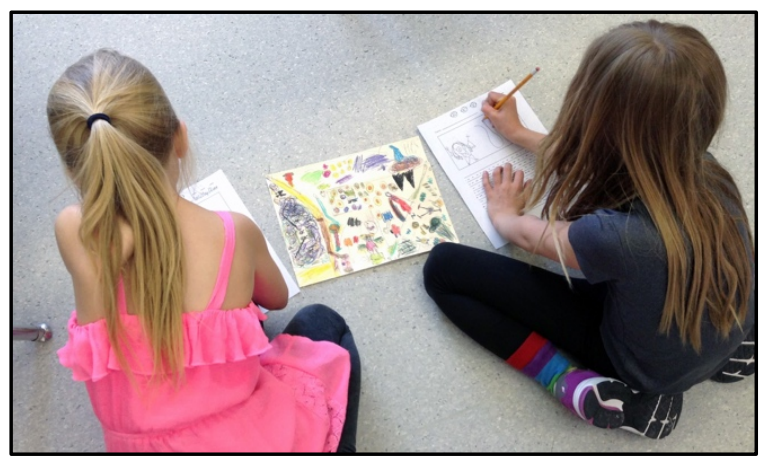

Figure 10. After collaborating to create an "onster" school, two Grade 1 girls extend the idea by writing their own stories

All the teachers found ways to integrate one or more forms or genres of writing/drawing that were created for authentic purposes. Text forms included posters, announcement scripts, recipes, diagrams, letters, labels, plans, narratives, information texts, questions and responses, research notes, signs, journal reflections, explanations, descriptions, map labels, banners, receipts, orders, labelled pictures, passports, travel brochures, tickets, lists, addresses, recounts, identification badges, prescriptions, construction challenges, graphic organizers, picture books, invoices, and inventory orders.

Additionally, students had many opportunities to learn through talk and nonverbal interactions with others. In 35 activities, learning objectives from other curriculum areas were also addressed, including Math, Science, Social Studies, Art, Drama, Technology and Design, and Physical Education.

The activities created spaces for students to use their imagination and creativity while interacting with peers and adults. We suggest that these activities embody the spirit of "guided play" (Weisberg, Hirsh-Pasek, \& Golinkoff, 2013), a playful, child-centered approach, "which incorporates adult-scaffolded learning but remains child-directed" ( $p$.105). We hope that teachers can draw from our analysis of these activities to incorporate play(ful) learning into their classrooms. They might start with a small initiative, such as modeling uses of writing at a play center and extend into themes and scenarios involving the collaborative creation of a wide range of texts. In the process, teachers will be drawing on research showing the importance of play to children's literacy and all learning, as well as addressing curriculum policy mandates. 


\section{TAKE ACTION!}

\section{In Kindergarten:}

- Talk with students about the different roles they might enact within a play center, including items that would support their role-play.

- While the children are playing, enter the center in role as a character, and model how writing might be used. Leave the writing materials for the children to explore independently.

In Grade 1:

- For your next science or social studies unit, encourage discussions about the different jobs that people might have, and the genres/forms of writing they might use, in relation to the topic. How might students explore these roles in short dramatizations? How might the students write in role?

- With the students, consider a few writing forms that they might use to reflect on their learning.

\section{MORE TO EXPLORE}

- Links to full descriptions of the action research activities mentioned in this paper: http://hdl.handle.net/1807/93059

- Flemington, K., Hewins, L., \& Villiers, U. (2011). Journey to literacy: No worksheets required. Markham, ON: Pembroke Publishers.

- Kaufman, E. (2015). Dramatic play in the early years. Markham, ON: Pembroke Publishers.

- Kobylak, K., \& Kalyn, B. (2017). Play and exploration in grade one: Extending the principles of early learning. Journal of Childhood Studies, 42(1), 32-44.

\section{ACKNOWLEDGEMENTS}

We wish to acknowledge that this research has been carried out on Indigenous land in the Treaty 3 Ojibwe First Nations, Treaty 8 Woodland Cree First Nation, and Treaty 9 Ojibway Nation territories. We are grateful to participating Indigenous community members for welcoming us to work and learn within their ancestral lands and thankful to participating children and their teachers, as well as the Social Science and Humanities Research Council of Canada for funding the research. 


\section{REFERENCES}

Anning, A. (2015). Play and the legislated curriculum. In J. Moyles (Ed.), The excellence of play ( $4^{\text {th }}$ ed.; pp. 3-13). Maidenhead, England: McGraw Hill Open University Press.

Bennett, N., Wood, L., \& Rogers, S. (1997). Teaching through play: Teachers' thinking and classroom practice. Buckingham, EN: Open University Press.

Bodrova, E., \& Leong, D. (2007). Tools of the mind: The Vygotskian approach to early childhood education $2^{\text {nd }}$ Ed. Upper Saddle River, NJ: Pearson.

Bodrova, E., \& Leong, D.J. (2015). Vygotskian and post-Vygotskian views on children's play. American Journal of Play, 7(3), 371-388.

Department for Education and Skills (DfES). (2013). Early years foundation stage. London: Author.

Gerde, H. K., Bingham, G. E., \& Wasik, B. H. (2012). Writing in early childhood classrooms: Guidance for best practices. Early Childhood Education Journal, 40(6), 351-359.

Harste, J. C., Burke, C. L., \& Woodward, V. A. (1984). Children's language and world: Initial encounters with print. In J. A. Langer \& M. T. Smith-Burke (Eds.), Reader meets Author/Bridging the Gap: A Psycholinguistic and Sociolinguistic Perspective. Newark: Delaware: International Reading Association.

Ihmeideh, F. (2015). The impact of dramatic play center on promoting the development of children's early writing skills. European Early Childhood Education Research Journal, 23(2), 250-263.

Moyles, J. (2015). Starting with play: Taking play seriously. In J. Moyles (Ed.), The excellence of play $4^{\text {th }}$ Ed. Maidenhead, EN: Open University Press.

Ontario Ministry of Education (2010). The full-day early learning kindergarten program, draft version. Toronto, $\mathrm{ON}$ : Author.

Pellegrini, A. D. (1980). The relationship between kindergartners' play and achievement in prereading, language, and writing. Psychology in the Schools, 17, 530-535.

Pellegrini, A. D., Galda, L., Dresden, J., \& Cox, S. (1991). A longitudinal study of the predictive relations among symbolic play, linguistic verbs, and early literacy. Research in the Teaching of English, 25(2), 219-235.

Peterson, S.S. (2015). Supporting primary students' writing through reading, talk, and literate dramatic play in primary classrooms (S.E. Sargent, Ed.). The Oklahoma Reader, 51(1), 22-24.

Peterson, S.S. (2016). Developing a play-based communication assessment through collaborative action research with teachers in northern Canadian Indigenous communities. Literacy, 51(1), 36-43.

Peterson, S.S., \& Portier, C. (2016, Summer). Teaching vocabulary and writing in kindergarten through dramatic play centres. Colorado Reading Journal, 27, 25-32. 
Quinn, M. F., Gerde, H. K., \& Bingham, G. E. (2016). Help me where I am: Scaffolding writing in preschool classrooms. The Reading Teacher, 70(3), 353-357. doi:10.1002/trtr.1512

Roskos, K., \& Christie, J. (2001). Examining the play-literacy interface: A critical review and future direction. Journal of Early Childhood Literacy, 1(1), 59-89.

Roskos, K., \& Christie, J. (2009). Play and literacy in early childhood: Research from multiple perspectives ( $2^{\text {nd }}$ ed.). New York, NY: Routledge.

Russell, J. L. (2011). From child's garden to academic press: The role of shifting institutional logics in redefining kindergarten education. American Educational Research Journal, 48(2), 236-267.

Saracho, O. N., \& Spodek, B. (2006). Young children's literacy-related play. Early Child Development \& Care, 176(7), 707-721. doi:10.1080/03004430500207021

Teale, W. H., \& Sulzby, E. (1986). Emergent literacy as a perspective for examining how young children become writers and readers. In W. H. Teale \& E. Sulzby (Eds.), Emergent literacy: Writing and reading (pp. vii-xxv). Norwood, NJ: Ablex Publishing Corporation.

Teale, W. H., Whittingham, C. E., \& Hoffman, E. B. (2018). Early literacy research, 2006-2015: A decade of measured progress. Journal of Early Childhood Literacy.

Vedeler, L. (1997). Dramatic play: A format for 'literate' language? British Journal of Educational Psychology, 67, 153-167.

Vygotsky, L. (1978). Mind in society. Cambridge, MA: Harvard University Press.

Weisberg, D. S., Hirsh-Pasek, K., \& Golinkoff, R. M. (2013). Guided play: Where curricular goals meet a playful pedagogy. Mind, Brain, and Education, 7(2): 104-112.

Weisberg, D. S., Hirsh-Pasek, K., Golinkoff, R. M., Kittredge, A. K., \& Klahr, D. (2016). Guided play: Principles and practices. Current Directions in Psychological Science, 25(3), 177-182.

Worthington, M., \& van Oers, B. (2017). Children's social literacies: Meaning making and the emergence of graphical signs and texts in pretense. Journal of Early Childhood Literacy, 17(2), 147-175. doi:10.1177/146879841 